Bucknell University

Bucknell Digital Commons

$10-2015$

\title{
Increasing Engagement in French and Francophone Studies: Structured Journaling on the Emotions in La Fayette's La princesse de Clèves
}

\section{Logan Connors}

Bucknell University, lc050@bucknell.edu

Follow this and additional works at: https://digitalcommons.bucknell.edu/fac_journ

Part of the French and Francophone Literature Commons, Reading and Language Commons, and the Scholarship of Teaching and Learning Commons

\section{Recommended Citation}

Connors, Logan. "Increasing Engagement in French and Francophone Studies: Structured Journaling on the Emotions in La Fayette's La princesse de Clèves." PMLA (2015) : 1476-1480.

This Article is brought to you for free and open access by the Faculty Scholarship at Bucknell Digital Commons. It has been accepted for inclusion in Faculty Journal Articles by an authorized administrator of Bucknell Digital Commons. For more information, please contact dcadmin@bucknell.edu. 
Increasing Engagement in French and

Francophone Studies: Structured Journaling on the Emotions in La Fayette's La princesse de Clèves

\section{LOGAN J. CONNORS}

LOGAN J. CONNORS is the NEH Chair in the Humanities and associate professor of French and francophone studies at Bucknell University. He is the author of Dramatic Battles in Eighteenth-Century France: Philosophes, Anti-philosophes and Polemical Theatre (Voltaire Foundation, 2012), a critical edition of Pierre de Belloy's Le siège de Calais (Mod. Humanities Research Assn., 2014), and numerous articles about French theater, the European Enlightenment, and literature pedagogy. In 2015 he edited a double issue of Restoration and Eighteenth-Century Theatre Research devoted to antitheatrical discourses in early modern Europe, and he is working on a book about theories of emotional response in the writings of antitheatricalists and proponents of the stage in early modern France.

\section{LITERARY REPRESENTATIONS OF EMOTIONS FASCINATE US AS READERS;} THEY CONNECT TO US LOGICALLY AND NATURALLY BECAUSE WE EXPErience in our daily lives many of the emotional events depicted in novels, plays, and poems. Students are intrigued by the similarities and differences between their everyday feelings and the emotions represented in literature. Emotions are thus interesting processes to study, and in classroom discussions and activities most students have something to say about them. For this reason, I use emotion (broadly defined) as an important subject of inquiry in my literature and culture classes. In what follows, I share a structured journaling assignment based on emotion that helps students read with more detail, improves their foreign language skills, and boosts their engagement with difficult subject matter.

Emotions are complex, socially constructed states that have "both cognitive and affective components" (Matravers 4). When we focus student reading, journaling, and discussion on the sources, deployments, manifestations, and consequences of emotion, we can benefit from the growing academic interest in emotion in the fields of neuroscience, psychology, and animal behavior, which are some of the most popular majors at my school and, according to a few recent studies, around the country. ${ }^{1}$ More significantly, reading, writing, and talking about emotion tap into the experienced reality of our college students-young and not-so-young adults who are going through periods of profound self-questioning and change. Recent changes to how I teach Madame de La Fayette's La princesse de Clèves in a survey class on French literature serve as examples of how to build transferable skills and boost the quality and attraction of courses through close-reading techniques and the analysis of emotion in novels. From a broader perspective, this close-reading assignment helps assert the knowledge-building power of the emotions and of fiction and perhaps even serves to combat several possible reasons behind student attrition in early modern French studies, a particularly vulnerable subfield in an already vulnerable discipline. ${ }^{2}$

(C) 2015 LOGAN J. CONNORS

PMLA 130.5 (2015), published by the Modern Language Association of America 
La Fayette's novel, published in 1678, at the height of Louis XIV's reign, is the centerpiece of my survey course of French literature and culture from the Middle Ages to the Revolution. The course is a requirement for the French and francophone studies major, yet students are often reluctant to enroll: many can't bring themselves to take the class until their senior year. Most have never been exposed to texts, in any language, from the medieval or early modern period, and some sophomores (who brave the class early in their studies) have never read a complete novel in French. The students' initial feelings of strangeness and distance vis-à-vis the size and difficulty of the texts and the remoteness of the periods in question are difficult to overcome. Halfway through the semester, we read our first long novel, La princesse de Clèves, a seventeenth-century masterpiece and grand classique of French literature that, despite its renown in the French canon, reveals a host of difficulties for my (mostly) American students. How do I get students through the first section of the novel-an onslaught of dates, characters, and relationships? How do I get them not to give up before the main narrative, the princess's story, even begins? And how do I overcome the seemingly impossible cultural differences between the rigid sixteenth-century court that Clèves and company navigate in the novel and the everyday experiences of my students?

I began teaching this course with a rather standard approach: I assigned the first thirty or so pages of La princesse de Clèves and then asked the students to tell what happened there, focusing on people, places, and things. If they better understood the plot of $\mathrm{La} \mathrm{Fa}$ yette's novel, I thought, they would be more motivated to continue reading. On the day when the first section was assigned, I asked such plot questions as, What is the relationship between the king and Diane de Poitiers? Who is the duc de Nemours? Which families are in conflict? Since when and why? I found that student motivation was determined by forces outside my control and pedagogy: students with a preexisting interest in literature seemed engaged; those who were in the class because it was a requirement or because they had a vague interest in history or general French culture or a desire to improve their French were not.

I decided to make a change: I refocused my emphasis from people, places, and things to the ambiguous emotional lexicon that characterizes early modern France and the inner lives of the characters in the novel. My primary goals remained the same: I wanted my students to read closely in order to engage with the text on a meaningful level. I wanted them to analyze formal elements of the narrative (character development, foreshadowing, stylistics) as well as cull information about early modern French society from the novel.

In this new version of my survey course, our discussion of the emotions starts before I assign any reading. In the classroom, the students and I examine together several passages in the first thirty pages that describe emotions. I draw the students' attention to terms such as "touché" (50), "modestie noble" (50), "respect” (51), "ambition” (53), "chaleur extraordinaire" (55), "reconnaissance" (61), and "inclination" (61). I do not provide much context; I ask the students what these words mean to them as twenty-first-century college students and urge them to pay attention while reading to the differences between their personal definitions and how the words are used by La Fayette. Then I assign a journal exercise in conjunction with the reading for the next class, inviting students to write about some of the emotion words that we had studied together in class. I ask them to contextualize, in the first part of the story, words like inclination, trouble, passion, rougeur, froideur, modestie, respect, and intelligence-words that La Fayette uses to describe the emotional events of the novel and that sometimes have radically different definitions today. I give 
each student a different word but assign the most ambiguous words (e.g., inclination and trouble) to multiple students if the class is large. (Although the number varies from year to year, there are typically between twelve and twenty-four students in my survey class.)

This change to how I approach the beginning of La princesse de Clèves boosted the energy of the class in discussions and overall student engagement with the novel. A student who was asked to work on trouble, for example, traced the term to a process of visual or touch perception that is catalyzed by social factors, such as the relationship between the person troubled and the one who troubles, the class and social status of both parties, and the layout of the venue in which the troubling occurs (a party, a ceremony, an intimate salon, etc.). The student then examined an instance in more detail, following the journal prompt "How is the emotion manifested: through a bodily change, a behavioral modification, or another process?" The student detailed the consequences of this moment of trouble, following the prompt "What happens in the story as a result of that emotional event?"

In class I invited students to write definitions of their words, using the context of the novel as justification. A student who examined trouble wrote, "Un trouble est un sentiment d'attirance sexuel immédiat, souvent vite caché sous une froideur forcée" ("Un trouble is a feeling of immediate sexual attraction that is often quickly hidden behind a forced coolness").

I found that this activity increased students' interest in the novel and in early modern society; students paid more attention to textual detail and to the complexity of La Fayette's use of language. Students correctly picked up on ambiguities in conceptions of the emotions during this period. They pointed out how some emotions seemed tied to immediacy and the body and others more to the mind. They saw how emotions changed behavior. They realized that La Fayette clev- erly used emotions to remind the reader of earlier events in the novel.

Through these in-class and homework activities, students saw firsthand that there was a lot of confusion over how the emotions worked in early modern times-a psychological ambiguity that undergirds the period yet provides for a host of exciting moments in La Fayette's novel. To introduce the students to research methods in early modern literature and specifically to the use of secondary sources in literary research and analysis, I discuss excerpts of several works by scholars of early modern emotionality, including, for example, Daniel Gross. In his analysis of early modern European philosophers, rhetoricians, and literary authors, Gross confirms this confusion during the period over the source, path, and goals of the passions. He argues that early modern writers wondered (like my students):

Are passions tangible "things" residing in the soul, or are they dispositions of the heart, or beliefs of the Mind? Is passion a matter of personal expression, or is it something essentially social that a person performs? Do they come from our interior, or from the things we perceive? Can they be measured and manipulated-their causes controlled-or do passions elude control by their very nature? Are they divine, diabolical, or human, and can we distinguish them according to their origin?

Gross's take on the passions shows my students that their confusion about the emotions in the novel is not a foreign language comprehension problem but a valid perception of the ambiguity of emotionality during early modernity. Thus, through primary-source research and discussion of secondary sources, my students enter the scholarly dialogue on literature and the emotions in early modern France.

This new approach to the beginning of $\mathrm{La}$ Fayette's novel did not change my fundamental course objectives: students still must use literary analysis and linguistic comprehension to 
figure out people, places, and things, but now they do so through the lens of emotion. For instance, they discussed the princess's immediate physiological response in the presence of a man owing to her mother's lessons on galanterie, the man's reputation, and the strict rules for eye contact at court. This discussion about emotion led to broader conversations about female education in early modern France, family values at the time, and the question of the reader's perspective in La Fayette's novel, which is often called the first psychological novel in European literature. This new focus on emotion continued to inform discussions of the novel until its conclusion, even though I originally had planned to use the strategy merely as a starting point-a way of jumping into the book's challenging first pages.

That early modern literature and culture are often more difficult for students to relate to than the novels, films, and other cultural discourses of more recent times concerns me, given that my research and teaching are grounded in early modernity and that relatability - a word often used by my students-is an increasingly critical criterion for text appreciation and course selection. But when course assignments and class discussions were focused on emotions, students enthusiastically related to the text because it evoked emotional events in their own lives, both serious and lighthearted, in a way that did not occur in previous versions of the course. Students uninterested in literature grasped the idea of emotion as a link between their lives and the lives of the characters in a book that was written hundreds of years ago.

Many students were quick to point out that, like the princess de Clèves, they often feel a physical change, like sweating or an increase in their heart rate, before being mindful of its origin in an emotion like embarrassment, shame, or anger. Some remarked that how they feel is influenced by their social settings. A student noted a difference in her ability to express sadness in the sorority wing of the dorm where she lives and in her home. This observation generated a fascinating discussion about the distinction between an emotion and its expression, leading us to reexamine the text in even finer analytic detail. Many students-and this is what I was waiting for-talked about how the complexity in the representation of emotions in $\mathrm{La}$ Fayette's novel is not too distant from current mind-body, emotion-knowledge, and affectcognition discussions in their psychology and biology courses. In other words, students argued that La princesse de Clèves, like the lectures and experiments in their cognitive and behavioral sciences courses, informs their understanding of how the emotions work.

Close reading proves that we cannot separate content from form in the literature classroom. It is a vital activity for comprehension, but it need not be a mere exercise in textual minutiae; close reading can also build bridges between distant worlds and everyday experiences. Yet, to provide students with more than a picture of the local or the specific and give them something to say beyond the text at hand, close-reading activities need to be structured or themed, like the emotional-lexicon assignment detailed in this essay. Through such exercises, students come to understand that analyzing fiction is as useful an exercise in knowledge building as the experiments and clinical observations that characterize disciplines in the natural and social sciences-the disciplines that students deem useful and that they are quick to call their first or real majors. In short, through the close analysis of emotions in works like La princesse de Clèves, ${ }^{4}$ courses in French and francophone studies emerge as valuable, professionalizing experiences for our students because the students learn (and realize explicitly that they have learned) at least one essential lesson from literature: that it helps us better understand ourselves, our family and friends, and our world. 


\section{NOTES}

1. Psychology's rise to prominence as an academic major is stunning. In 1990 four-year colleges in the United States awarded approximately 55,000 bachelor's degrees in psychology; by 2008 that number had jumped to 92,000 (Halonen 4). Neuroscience, a smaller discipline, has also witnessed a meteoric rise in popularity. In 2000 approximately 600 students graduated from a four-year college with a degree in neuroscience; by 2008 the number had grown to approximately 2,100. In 1996 23 schools offered the major; in 2008105 did (Ramos et al. 67).

2. The percentage of schools that offer a major in any Romance language has plummeted from seventy-six percent in 1976 to fifty-one percent in 2006; this number is certainly worse now, following the closing of several language departments after the 2008-09 recession (Brint et al.).

3. The novel begins on page 37 in the Folio classique edition of La princesse de Clèves.

4. For another example of how I bring the analysis of early modern emotions into the undergraduate classroom, see my case study on teaching the abbé Prévost's Manon Lescaut in Connors, Dupont, and Westbrook (111-16).

\section{Works Cited}

Brint, Steven, et al. "Declining Academic Fields in U.S. Four-Year Colleges and Universities, 1970-2006." U.S. Department of Education Statistics Report. Rpt. in Chronicle of Higher Education. Chronicle of Higher Educ., 14 Feb. 2011. Web. 22 Nov. 2013.

Connors, Logan J., Nathalie Dupont, and John Westbrook. "Three Strategies for Promoting Intellectual Engagement in Advanced Undergraduate Seminars." French Review 87.4 (2014): 111-26.

Gross, Daniel M. The Secret History of Emotion: From Aristotle's Rhetoric to Modern Brain Science. Chicago: $\mathrm{U}$ of Chicago P, 2006. Print.

Halonen, Jane S. "Are There Too Many Psychology Majors?" White Paper Prepared for the Florida Board of Governors. Council of Graduate Depts. of Psychology, 5 Feb. 2011. Web. 15 Jan. 2014.

La Fayette, Madeleine Pioche de La Vergne de. La princesse de Clèves. 1678. Paris: Gallimard, 2000. Print. Folio classique.

Matravers, Derek. Art and Emotion. Oxford: Clarendon, 2005. Print.

Ramos, Raddy L., et al. "Undergraduate Neuroscience Education in the U.S.: An Analysis Using Data from the National Center for Education Statistics." Journal of Undergraduate Neuroscience Education 9.2 (2011): 66-70. Print. 